\title{
DIVERSITY AND SUMMER DISTRIBUTION OF CETACEANS IN INLET WATERS OF NORTHERN AISÉN, CHILE.
}

\author{
DIVERSIDAD Y DISTRIBUCIÓN ESTIVAL DE CETÁCEOS EN AGUAS INTERIORES DEL \\ NORTE DE AISÉN, CHILE.
}

José Zamorano-Abramson', Jorge Gibbons "I \& Juan Capella III IV

\begin{abstract}
Although the presence of 26 cetaceans species in channels and fjords of southern Chile has been already documented (Aguayo-Lobo et al. 1998), to date there is little published information available about diversity, distribution and habitat preferences. Progress in knowledge on populations of cetaceans in the region has been mainly achieved in the Straits of Magellan from several studies conducted since 1960`s (compiled by Lescrauwaet \& Gibbons $2008^{1}$ ). Recently some authors have pointed out that there seems to be a knowledge gap on cetaceans in northern Patagonian fjords, mainly inshore waters of Aisén, with only a low number of studies with a few published results.

Aguayo-Lobo et al. (1998) compiled records of 6 species of cetaceans for southern Chiloé and Aisén region: right whale Eubalaena australis (Desmoulins, 1822), Chilean dolphin Cephalorhynchus eutropia (Lacépède, 1804), right whale dolphin Lissodelphis peronii (Lacépède, 1804), Peale's dolphins Lagenorhynchus australis (Peale, 1848), dusky dolphins Lagenorhynchus obscurus (Gray, 1828) and Burmeister's porpoise Phocoena spinnipinis (Burmeister, 1865). In a recent descriptive study of marine mammals in the Los Chonos Archipelago
\end{abstract}

area (433' to $45^{\circ} 50^{\prime}$ S) by Aguayo-Lobo et al. (2006), authors showed that Peale's dolphins and bottlenose dolphins Tursiops truncatus (Montagú, 1821) among small cetaceans and sperm whales Physeter catodon, (Linnaeus, 1758) blue whales Balaenoptera musculus (Linnaeus, 1758) and Sei whale Balaenoptera borealis (Lesson, 1828) among great cetaceans were the species more frequently recorded.

A feeding ground of blue whales was reported in the Gulf of Corcovado, Archipelago de los Chonos (Hucke-Gaete et al. 2003) and off northwestern Chiloé Island (Cabrera et al. 2005). In this last area a summer aggregation of humpback whales has been reported as well (Galletti et al. 2006², 2008 3 , Hucke-Gaete et al. 2006 ${ }^{4}$ ), and photographic identification has confirmed movements and interchange of humpback whales individuals within the Strait of Magellan near Carlos III Island (Capella et al. 2008).

Systematic sighting surveys of small cetaceans (mainly Chilean and Peale's dolphins in southern Chiloé Island and Chiloé Archipelago conducted in austral summer and autumn since 2001, showed high residence and high fidelity of dolphins to shal-

\footnotetext{
${ }^{1}$ Lescrauwaet, A.K.L. \& J. Gibbons 2008. A review of the crab bait related exploitation of small cetaceans in Magallanes and Tierra del Fuego with an update on the current situation. SC/60/SM5.

${ }^{2}$ Galletti, B., C. Carlson, E. Cabrera \& R.L. Brownell Jr. 2006. Blue, sei and humpback whale sightings during 2006 field season in northwestern Isla de Chiloe, Chile. Paper SC/58/SH17 presented to the International Whaling Commission Scientific Committee, St. Kitts and Nevis, May 2006 (unpublished). 6pp.

${ }^{3}$ Galletti, B., C. A. Carlson, E. Cabrera, J. Capella \& R.L. Brownell, Jr. 2008. Recent humpback whale sightings off Isla de Chiloe, $2006-2008$. Paper SC/60/SH26 presented to the Scientific Committee of the International Whaling Commission, June 2008, Santiago, Chile.

${ }^{4}$ Hucke-Gaete, R., J. P. Torres-Flórez, F. A. Viddi, S. Cuellar, Y. Montecinos \& J. Ruiz 2006. A new humpback whale (Megaptera novaeangliae) feeding ground in northern Patagonia, Chile: extending summer foraging ranges. Report SC/58/SH10 to the Scientific Committee of the International Whaling Commission. St Kitts and Nevis. $16-20$ June.
}

\footnotetext{
${ }^{1}$ Dpto. Psicobiología. Universidad Complutense de Madrid. jfzabramson@gmail.com

"Laboratorio de Zoología, Instituto de la Patagonia, Universidad de Magallanes.

III Fundación Yubarta, Cali, Colombia.

Iv Whalesound Ltda, Punta Arenas, Chile
} 
low and close to shore waters with estuarine influence (Christie 20055 ${ }^{5}$, Heinrich 2006 ${ }^{6}$, Fuentes \& Heinrich $2007^{7}$, Heinrich et al. 2008 ${ }^{8}$ ).

Surveys of cetaceans carried out from December 2000 to November 2001 from Puerto Montt to south of Taitao Peninsula (41 $83^{\circ}$ and $48^{\circ} 00^{\prime} \mathrm{S}$ ) in northern Patagonian fjords, and in the waters off Puquitin, Leucayec and in Cumau Fjord, have showed spatial and seasonal variability of cetacean distribution in the fjords (Viddi et al. 2010). Mysticetes were distributed along a north - south gradient with preferences for open gulfs with oceanic influence, and close to shore. In contrast, odontocetes were observed mainly within narrow channels, areas with complex coastal morphology, peaking at different water depths (Viddi et al. 2010).

In this paper we present results on diversity, local distribution and group composition of cetacean species along inshore waters of the fjord Puyuhuapi and Channels Jacaf and Moraleda (between $44^{\circ} 00^{\prime}$ and $46^{\circ} 00^{\prime}$ 'S), northern Aisén (Fig.1), obtained in an opportunistic way while we were recording underwater dolphins vocalizations, with the aim to contribute to cetacean basic knowledge in the inlet waters of southern Chile.

Fieldwork was conducted at the end of the summer season 2009, from 24th February through 26th March, with 194 hours of navigation effort accomplished in 23 days. Surveys were performed on a $5 \mathrm{~m}$ rigid boat with a $40 \mathrm{HP}$ outboard two stroke engine. We navigated at 8 knots or less maintaining a distance of about $50-200 \mathrm{~m}$ off the coast, consistent with higher likelihood to observe Chilean dolphin, Peale's dolphin and Burmeister's porpoise suggested for the species in southern Chile (Gibbons et al. 2001, Ribeiro et al. 2005, Viddi \& Lescrauwaet 2007). One or two observers scanned the area looking for cetacean, alternating naked eye and binoculars ( $7 \times 40)$, in conditions of Beaufort 3 or less and visibility higher than $500 \mathrm{~m}$. The navigation tracks were recorded taking position by a portable GPS (Fig.1). Survey effort varied within the study area, being a $50 \%$ concentrated on the head of the Puyuhuapi Fjord.
Whenever cetaceans were sighted, the track was interrupted in order to identify the species and to record group geographical position (GPS), group size and individual composition by photoidentification. During these 23 days it was possible to obtain colour photographs suitable for individual identification, based on long-term natural marks on the dolphins' dorsal fins (Wursig \&Wursig 1977). At each encounter with a group of dolphins an attempt was made to obtain as many good photographs as possible of all individuals present, throughout the duration of the observation. Photo-identification was performed following Wursig \& Jeferson (1990), with a NIKON D300 digital camera equipped with NIKON 100-400-zoom lenses at 5-50 m of the animals, considering that digital photography substantially improves the efficiency of individual dolphin identification (Markowitz et al. 2003). Digital photos were then cropped around the dorsal fin and visible part of the body and selected using consistent criteria (i.e. entire dorsal fin visible, fin perpendicular to camera, high sharpness and resolution, no water spray masking fin profile), based on recommendations provided by Read et al. (2003). Dorsal fin pigmentation patterns, nicks, scars, edge detail, tooth rakes and skin lesions were used to identify individuals across the different species within the population.

We obtained sightings of 86 groups of five species of cetaceans: Peale's dolphins (Fig.2), Chilean dolphins (Fig.3), bottlenose dolphins (Fig.4), Burmeister's porpoises (Fig.4) and blue whales (Fig.4). Peale's dolphin was the most common species with 55 groups sightings over 21 different days, followed by Chilean dolphin, with 17 groups sightings in 9 days. The ones sighted with lesser frequency were Burmeister's porpoise, with 8 groups sightings in 6 days, blue whale with 4 groups and bottlenose dolphin with 2 groups sightings (Table 1). Peale's and Chilean dolphin, the most frequently encountered species, did not distribute uniformly but occurred predominantly in shallow near shore waters on the head of the Puyuhuapi Fjord (67.3 and $88.2 \%$ of the sightings weighted by survey effort). Incidences of overlap of Chilean and Peale's dolphins were

\footnotetext{
${ }^{5}$ Christie, C. 2005. Niveles de organización social del delfín chileno Cephalorhynhcus eutropia (Gray 1846) y del delfín austral Lagenorhynchus australis (Peale.1848) en la isla de Chiloé, X región, Chile. Tesis de biología marina. Universidad Austral de Chile, Valdivia

${ }^{6}$ Heinrich, S. 2006. Ecology of Chilean dolphins and Peale's dolphins at Isla Chiloe, southern Chile. Ph.D. Thesis. University of St Andrews, St. Andrews, UK (239pp.).

${ }^{7}$ Fuentes, M. \& S. Heinrich 2007. Toninas en el sur del archipiélago de Chiloé. Ecología de conservación del delfín chileno y delfín austral. Resumen del estudio de pequeños cetáceos en el sur de Chiloé desde 2001. Informe técnico para el departamento de turismo de la ilustre Municipalidad de Quellón.

${ }^{8}$ Heinrich, S., M. Fuentes \& P.S. Hammond 2008. Conservation status of small cetaceans in the Chiloé Archipelago, southern Chile. Paper SC/60/SM23 presented to the IWC Scientific Committee, June 2008 (unpublished). 12pp.
} 
observed four times. On two occasions the Chilean dolphins chase Peale's dolphins and on two others we observed just neutral passes.

The largest groups were found on bottlenose dolphins with group sizes of about 100 individuals. Peale's and Chilean dolphins were seen in small groups, varying from $1-20$ for Peale's dolphins and 2-25 for Chilean dolphins. Burmeister's porpoises group size range was $2-7$ and blue whales 2-11. For Peale's dolphins, a total of 29 marked individuals out of 330 (12.4\%) were photographically identified. Only three individual Peale's dolphins where resighted, one in four non consecutive days between a maximum interval of one week. The maximum interval was 25 days between March 1st and 26 for one mother-calf dyad and also for one adult male, all on the head of Puyuhuapi Fjord. The other two sightings were made on consecutive days. For Chilean dolphins, a total of 13 marked individuals out of 92 were photographically identified (12\%). Five individual Chilean dolphin were resighted, with a maximum of four different non consecutive days for one female with her calf. For bottlenose dolphins, 26 out of 200 (10.3\%) and for blue whales 8 from $23(34.8 \%)$ were distinctively marked with fin nicks, tooth rakes and skin lesions documented via photo ID. Furthemore, two bottlenose dolphins (one adult and one juvenile) and none blue whales individuals were resighted.

These new 86 groups sightings of cetaceans in the Puyuhuapi - Moraleda area reported here represent an important number of records in comparison with all Aisén coast sightings collected between 1964 and 1998 by Aguayo-Lobo et al. (1998). The near shore habits of the small cetaceans species have been documented by Goodall et al (1988, 1995, 1997), Gibbons et al. (2001), Ribeiro et al. (2005), Viddi \& Lescrauwaet (2007) and Viddi et al. (2010).

In general, the composition of species is similar to what is known for other areas of southern Chile. In Guaitecas archipelago, Viddi (2010) found Peale's dolphin, Chilean dolphin, killer whale Orcinus orca (Linnaeus, 1758), bottlenose dolphin and Burmeister's porpoise. In Chiloé Island, Chilean dolphins occurred mainly in several southern selected bays and channels (Heinrich et al 2008). Peale's dolphins were distributed more widely, particularly in central Chiloé. Burmeister's porpoises were sighted regularly at two locations in central and in one channel in southern Chiloé (Fuentes \& Heinrich 2007). Blue whale sightings obtained in this study match with the southern distribution limits found by Hucke et al. (2004).

In the inshore waters southern of the Golfo de Penas, four species of cetaceans were more commonly recorded: Peale's dolphin, Chilean dolphin, humpback whale, and killer whale. Burmeister's porpoise is very rare and can be found only in the Beagle Channel (Gibbons et al. 2001, Goodall et al. 1995). In the Straits of Magellan the most frequent species are Peale's dolphin, humpback whale, Commersson's dolphin (Lacépède, 1804) and killer whales. The bottlenose dolphin is rare in Chilean fjords (Olavarria et al. submitted), but in recent years the species has been recorded in the Straits of Magellan, suggesting that it is becoming more common in the last decade.

Our results confirmed that Peale's dolphin and Chilean dolphin are the most frequent small cetacean species $(65.5 \%$ and $20.2 \%$ of the sightings respectively) that inhabit in most of the sheltered areas of southern Chile as it has been documented in the region (Goodall et al. 1988, 1997, Goodall 1994, Viddi et al. 2010). An exception is the eastern Strait of Magellan where Commerson's dolphin is the most common one (Lescrauwet et al. 2000). In Aisén, the Chilean dolphin seems to be the most frequent species of small cetaceans in the north of Laguna San Rafael. It is important to note that although reported in this study, the Burmeister's porpoise is very rare in the inshore southern Chile. Our results also confirmed that bottlenose dolphin is the cetacean that shows the largest group size observed (Viddi et al. 2010).

Our data are concentrated on the inshore waters of Aisén. For this reason, the information presented here, besides being consistent with, complement Viddi et al. (2010) study, that showed that the Moraleda channel and associated fjords and channels, especially those close to the Aisén fjord, seem to be a hotspot for odontocetes.

Spatial overlap between the dolphins and salmon and trout farming was extensive in Puyuhuapi Fjord. Different authors argue that aquaculture farms may negatively affect the Peale's and Chilean dolphin distribution (Heinrich 2006l) and behavior (Ribeiro et al. 2005, 2007). An ecosystem approach 
is needed to assess impacts of salmon farming and whale watching on coastal cetacean in southern Chile (Buschmann et al. 2006). The study area with a high density coastal cetacean although seems to have a high potential for commercial activities related to whale watching. From a management perspective, information on the occurrence of cetaceans in the area will help to introduce them to the regional planning authorities.

To date there is no published information about interchange of individuals of small cetaceans among different regions of southern Chile. In the future the comparison among photo-identification catalogues of individual cetaceans that have been developed by different organizations at Chiloé, Aisén, Patagonian and Fuegian fjords and the Straits of Magellan, will be very useful to discover possible movements and interchange of individuals along the southern Chilean coast.

TABLE 1. Records of cetaceans sightings in inlet waters of northern Aisén.

\begin{tabular}{cccccc}
\hline species & peale's dolphin & chilean dolphin & bottlenose dolphin & $\begin{array}{c}\text { Burmeister's } \\
\text { porpoise }\end{array}$ & blue whale \\
$\mathrm{N}^{\circ}$ groups & 55 & 17 & 2 & 8 & 4 \\
$\mathrm{~N}^{\circ}$ individual & 330 & 92 & 200 & 26 & 23 \\
modal size & 10 & 2 & 100 & 2 & 3 \\
\hline
\end{tabular}

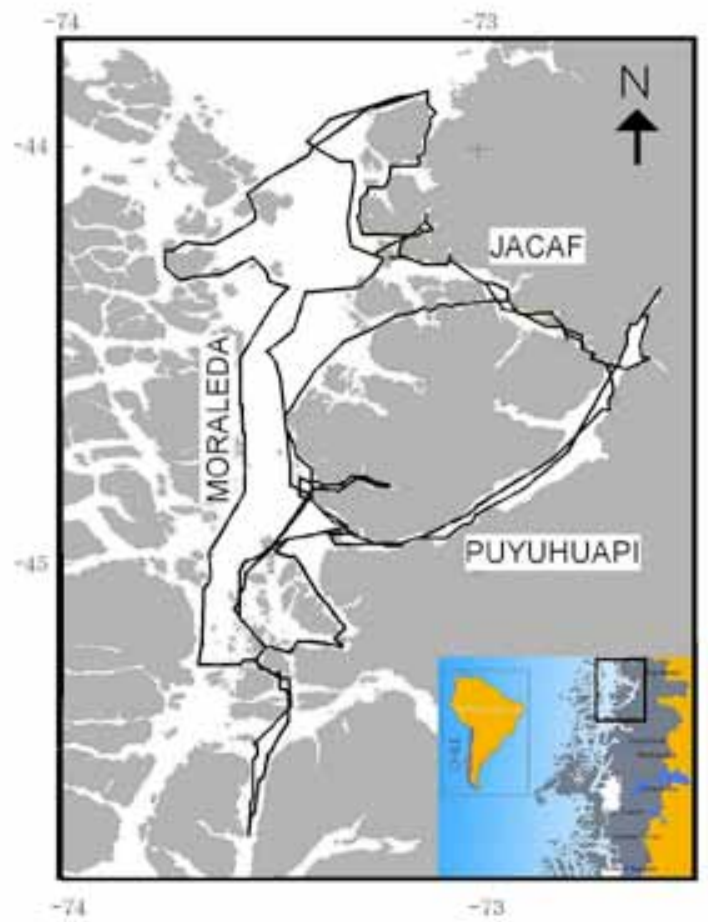

Fig. 1. Cetacean survey tracks in inlet waters of northern Aisén. 


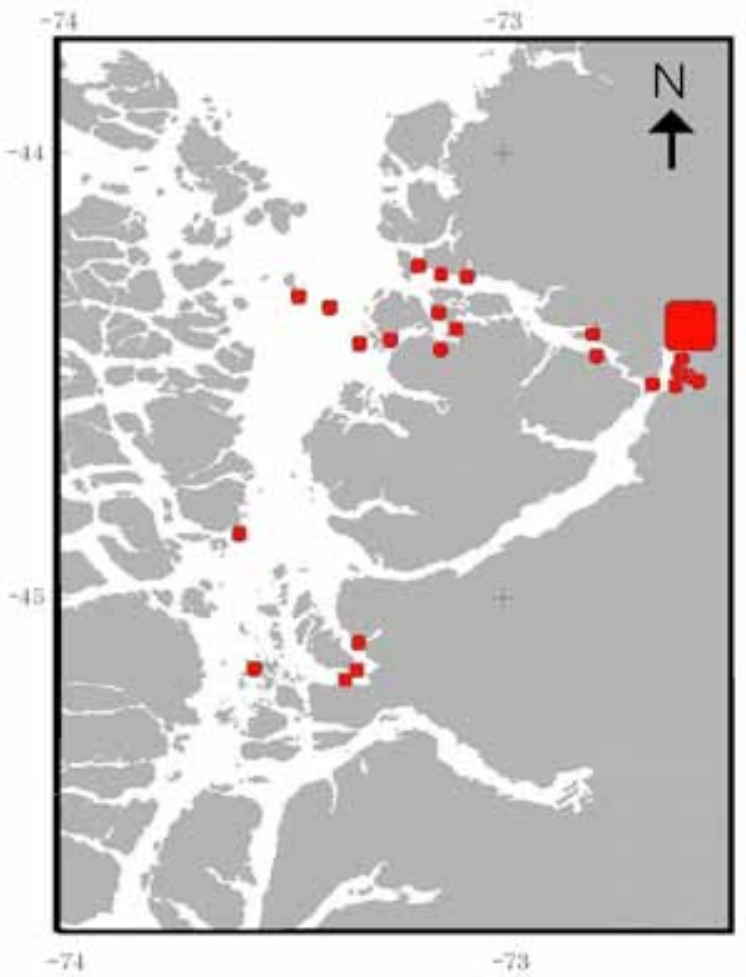

Fig. 2. Distribution of the Peale's dolphin sightings (dots) in inlet waters of northern Aisén.

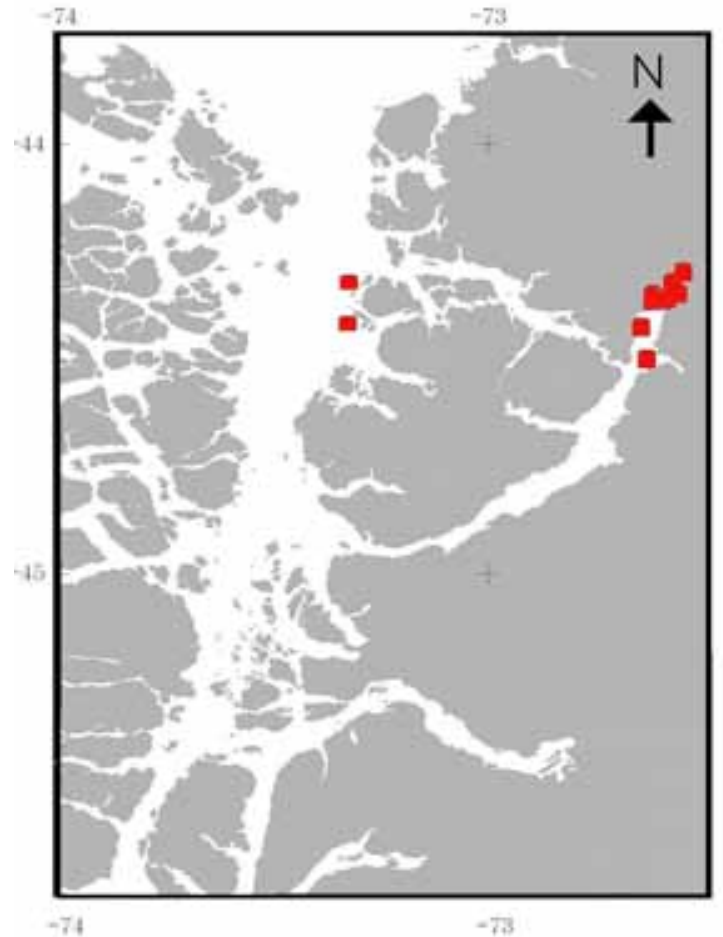

Fig.3. Distribution of Chilean dolphin sightings (dots) in inlet waters of northern Aisén. 


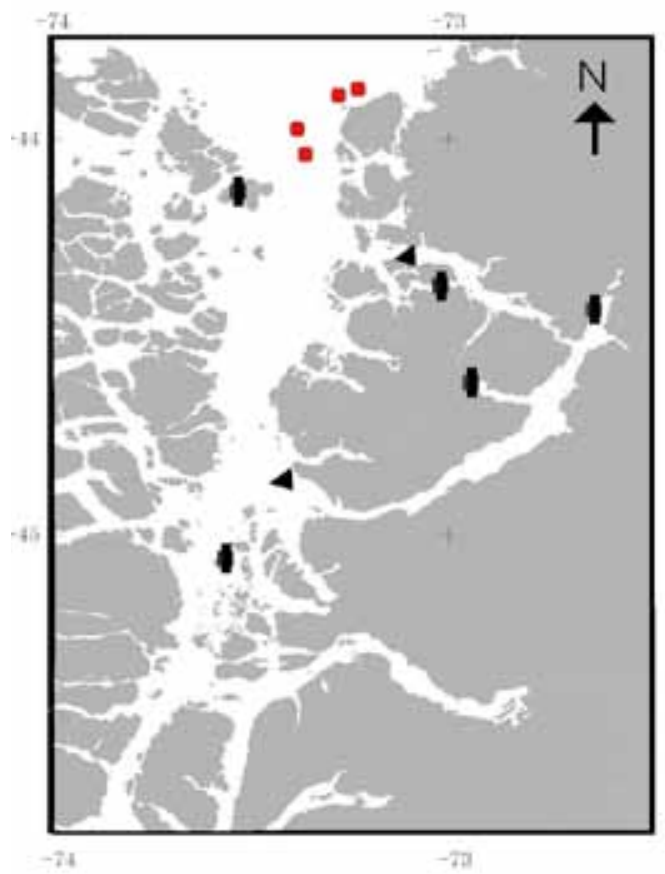

Fig. 4. Distribution of blue whale (dots), Burmeister's porpoise (crosses) and bottlenose dolphin (triangle) sightings in inlet waters of northern Aisén..

\section{ACKNOWLEDGMENTS}

Research reported in this study was supported by project grants D/010828/07 and D/010828/08 "Acción Integrada Universidad Complutense de Madrid - Universidad de Magallanes" from the AECID (Agencia Española de Cooperación Internacional y Desarrollo), (IP. Fernando Colmenares); and by INNOVA Corfo (IP. Jorge Gibbons). José Zamorano - Abramson also wants to thank to the local fishermen from Puyuhuapi, Juan Fuentes and his son Camilo Fuentes, for their help and for keeping him safe while navigating through the fjords.

\section{LITERATURE CITED}

Aguayo-Lobo, A, J. Acevedo \& R. Vargas-Morales 2006. Diversidad de mamíferos marinos en las aguas del Archipiélago de los Chonos

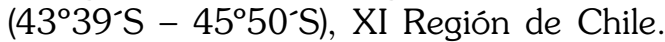
Revista Ciencia y Tecnología del Mar 29: 129-145.
Aguayo-Lobo, A., D. Torres \& J. Acevedo 1998. Los mamíferos marinos de Chile: I. Cetácea. Ser. Cient. Inach $\mathrm{N}^{\circ} 48$ : 19-159.

Buschmann, A.H., V.A. Riquelme, M.C. HernándezGonzález, D. Varela, J.E. Jiménez, L.A. Henríquez, P.A. Vergara, R. Guinez \& L. Filun 2006. A review of the impacts of salmonid farming on marine coastal ecosystems in the Southeast Pacific. ICES Journal of Marine Science, 63(7): 1338-1345.

Cabrera, E., C. Carlson \& B. Galleti 2005. Presence of blue whale (Balaenoptera musculus) in the northern coast of Chiloé Island, southern Chile. LAJAM 4(1): 73 - 74. ISSN 1676 - 7497.

Capella, J., B. Galleti, J. Gibbons \& E. Cabrera 2008. Coastal migratory connections of Humpback whales, Megaptera novaeangliae Borowski, 1781, in Southern Chile. Anales Instituto Patagonia (Chile) 36: 13-18. Goodall, R.N.P. 1994. Chilean dolphin Cephalorhynchus eutropia (Gray, 1846). Pp: 269-287, In: Ridgway SH \& SR Harrison (eds) Handbook of marine mammals, Volume 5, Academic Press, San Diego. 
Goodall, R.N.P., B. Wursig, M. Wursig, G. Harris \& K. Norris 1995. Sightings of Burmeister's porpoise, Phocoena spinipinnis, off southern South America. Rep. int. Whal. Commn (Special Issue) 16:297-316.

Goodall, R.N.P., K. Norris, A. Galeazzi, J. Oporto \& I. Cameron 1988. On the Chilean dolphin Cephalorhynhcus eutropia (Gray 1846). Rep. int. Whal. Commn (Special Issue) 9: 197-258.

Goodall, R.N.P., K. Norris, J. De Haro, M. Iñiguez \& F. Fraga 1997. Sightings and behavior of Peale's dolphins, Lagenorhynchus australis with notes on dusky dolphins, L. obscurus, off Southernmost South America. Rep. int. Whal. Commn 47: 757-775.

Hucke-Gaete, R., L.P. Osman, C.A. Moreno, K.P. Findlay \& D.J. Ljungblad 2003. Discovery of a blue whale feeding and nursuring ground in southern Chile. Proc. R. Soc. Lond. Ser. B (Suppl.) Biology Letters 271, S170 - S173.

Lescrauwaet, A.K. 1996. Notes on the behaviour and ecology of the Peale's dolphin, Lagenorhynchus australis, in the Magellan Strait, Chile. Rep. Int. Whal. Commn 47: 747-755.

Lescrauwaet, A.K., J. Gibbons, L. Guzmán \& A. Schiavini 2000. Abundance stimation of Commerson's dolphin in the strait of Magellan, Chile. Revista Chilena de Historia Natural 73: 473 - 478 .

Markowitz, T.M., A.D. Harling \& B. Wursig 2003. Digital photography improves eficiency of individual dolphin identification. Marine $\mathrm{Ma}$ mmal Science 19: 217-223.

Olavarría, C., J. Acevedo, H.I. Vester, J. ZamoranoAbramson, F.A. Viddi, J. Gibbons, E. Newcombe, J. Capella, A. Rus Hoelzel, M. Flores, R. Hucke-Gaete \& J.P. Torres-Flórez (submitted) Southernmost distribution of common bottlenose dolphins (Tursiops truncatus) in the eastern South Pacific. Revista de Biologia Marina y Oceanografia
Read, A.J., K.W. Urian, B. Wilson \& D.M. Waples 2003. Abundance of bottlenose dolphins in the bays, sounds and estuaries of North Carolina. Marine Mammal Science 19: 59-73.

Ribeiro, S., F.A. Viddi, \& T.R.O. Freitas 2005. Behavioural responses by Chilean dolphins (Cephalorhynchus eutropia) to boats in Yaldad bay, southern Chile. Aquatic Mammals 31(2):234-242.

Ribeiro, S., F.A. Viddi, J.L. Cordeiro, \& T.R.O. Freitas 2007. Fine-scale habitat selection of Chilean dolphins (Cephalorhynchus eutropia): interactions with aquaculture activities in southern Chiloé Island, Chile. Journal of the Marine Biological Association of the United Kingdom 87(1), 119-128.

Sielfeld, W. \& C. Venegas 1978. Observaciones de delfínidos en los canales australes de Chile. Anales Instituto Patagonia (Chile) 9:145-52.

Viddi, F. \& A.K. Lescrauwaet 2005. Insights on habitat selection and behavioural patterns of Peale's dolphins (Lagenorhynchus australis) in the Strait Magellan, Southern Chile. Aquatic Mammals. 31(2):176-183.

Viddi, F. A., R. Hucke-Gaete, J. P. Torres-Florez, \& S. Ribeiro 2010. Spatial and seasonal variability in cetacean distribution in the fjords of northern Patagonia,

Chile. - ICES Journal of Marine Science, 67: $000-000$.

Wursig, B. \& T.A. Jeferson 1990. Methods of photoidentification for small cetaceans. Report of the International Whaling Commission, Special Issue no. 12: 43-52.

Wursig, B. \& M. Wursig 1977. The photographic determination of group size, composition, and stability of coastal porpoises (Tursiops truncatus). Science 198: 755-756. 